\title{
Dynamic DNA Methylation in Plant Growth and Development
}

\author{
Arthur Bartels ${ }^{1,+}{ }^{\text {, Qiang Han }}{ }^{1,+} \mathbb{C}^{\mathbb{D}}$, Pooja Nair ${ }^{1, \ddagger}$, Liam Stacey ${ }^{1}$, Hannah Gaynier ${ }^{1}$, \\ Matthew Mosley ${ }^{1}$, Qi Qing Huang ${ }^{1}$, Jacob K. Pearson ${ }^{1}$ (1) , Tzung-Fu Hsieh ${ }^{2,3}$, \\ Yong-Qiang Charles An ${ }^{4}$ and Wenyan Xiao ${ }^{1, *}$ \\ 1 Department of Biology, Saint Louis University, St. Louis, MO 63103, USA; arthur.bartels@slu.edu (A.B.); \\ qiang.han@slu.edu (Q.H.); pnair2013@gmail.com (P.N.); liam.stacey@slu.edu (L.S.); \\ hannah.gaynier@slu.edu (H.G.); matthew.mosley@slu.edu (M.M.); qiqing.huang@slu.edu (Q.Q.H.); \\ jacob.pearson@slu.edu (J.K.P.) \\ 2 Department of Plant and Microbial Biology, North Carolina State University, Raleigh, NC 27695, USA; \\ thsieh3@ncsu.edu \\ 3 Plants for Human Health Institute, North Carolina State University, North Carolina Research Campus, \\ Kannapolis, NC 28081, USA \\ 4 Plant Genetics Research Unit, Donald Danforth Plant Science Center, Midwest Area, Agricultural Research \\ Service, US Department of Agriculture, St. Louis, MO 63132, USA; yong-qiang.an@ars.usda.gov \\ * Correspondence: wenyan.xiao@slu.edu; Tel.: +1-314-977-2547 \\ + These authors contributed equally to this work. \\ $\ddagger$ Current address: School of Medicine, University of Missouri at Columbia, Columbia, MO 65203, USA.
}

Received: 20 June 2018; Accepted: 20 July 2018; Published: 23 July 2018

Abstract: DNA methylation is an epigenetic modification required for transposable element (TE) silencing, genome stability, and genomic imprinting. Although DNA methylation has been intensively studied, the dynamic nature of methylation among different species has just begun to be understood. Here we summarize the recent progress in research on the wide variation of DNA methylation in different plants, organs, tissues, and cells; dynamic changes of methylation are also reported during plant growth and development as well as changes in response to environmental stresses. Overall DNA methylation is quite diverse among species, and it occurs in $\mathrm{CG}, \mathrm{CHG}$, and $\mathrm{CHH}(\mathrm{H}=\mathrm{A}, \mathrm{C}$, or T) contexts of genes and TEs in angiosperms. Moderately expressed genes are most likely methylated in gene bodies. Methylation levels decrease significantly just upstream of the transcription start site and around transcription termination sites; its levels in the promoter are inversely correlated with the expression of some genes in plants. Methylation can be altered by different environmental stimuli such as pathogens and abiotic stresses. It is likely that methylation existed in the common eukaryotic ancestor before fungi, plants and animals diverged during evolution. In summary, DNA methylation patterns in angiosperms are complex, dynamic, and an integral part of genome diversity after millions of years of evolution.

Keywords: DNA methylation; methylome; seed; development; gene expression; dynamics; epigenetics; transposable element; plant

\section{Introduction}

DNA methylation generally refers to an addition of a methyl group onto the C5 position of cytosine to form 5-methylcytosine (5mC). DNA methylation is an important epigenetic mechanism that is involved in transposable element (TE) silencing, genome stability, X-chromosome inactivation, and genomic imprinting. DNA methylation in promoters has been shown to regulate gene expression and plays a critical role in the growth and development of plants and mammals. DNA methylation 
in the symmetric CG context is an evolutionarily conserved modification in plants, mammals and some fungi [1-4]. In mammals, DNA methylation is initiated by de novo DNA methyltransferase 3 (Dnmt3) [5] and maintained by DNA methyltransferase 1 (Dnmt1) [6]. In higher plants, in addition to CG methylation, DNA methylation also occurs in the CHG (symmetric) and $\mathrm{CHH}$ (asymmetric) contexts ( $\mathrm{H}=\mathrm{A}, \mathrm{C}$, or T). In Arabidopsis, DNA METHYLTRANSFERASE 1 (MET1), an ortholog of Dnmt1 in mammals, maintains CG methylation [7-10]. CHROMOMETHYLASE 2 and 3 (CMT2 and CMT3) [11-13] and the de novo DNA methyltransferases DOMAINS REARRANGED METHYLTRANSFERASE 1 and 2 (DRM1 and DRM2) [14,15] are mainly responsible for DNA methylation at the CHG and CHH contexts. Oryza sativa (rice) has OsMET1-1 and OsMET1-2, Prunus persica (peach) has one PsMET, and Zea mays (maize) has one ZmMET1 [16-18]. For the CMT family, Brassica rapa has one BrCMT [19], rice has two OsCMTL and OsMET2a but their functions have not been confirmed, and Zea mays has two ZMET2 and ZMET5 [20]. For the DRM family, Oryza sativa and Zea mays each have two homologous proteins OsDMT106 and OsZmet3, ZmDMT106 and Zmet3, respectively, but their biological functions are not known [21].

DNA methylation used to be thought as static: methylation on DNA remains there after being added by DNA methyltransferases. However, DNA demethylation can occur passively during DNA replication when a newly synthesized strand is not methylated by DNA methyltransferases, or it can occur actively to remove 5-methylcytosines by the base excision repair (BER) pathway in plants. The discoveries of DNA demethylases DEMETER (DME) and REPRESSOR OF SILENCING 1 (ROS1) show that the methylation process can be actively reversed. Both DME and ROS1 encode DNA glycosylase, which catalyzes reactions to actively remove 5-methylcytosine through the BER pathway. Active DNA demethylation has also been found in mammals: demethylation can be achieved by ten-eleven translocation (TET) dioxygenases to form 5-hydroxymethylcytosine (5-hmC) through oxidation of the methyl group, and then $5-\mathrm{hmC}$ is converted into unmodified cytosines by DNA glycosylase-mediated BER. In plants, $\mathrm{CHH}$ methylation can occur through the siRNA-mediated RNA-directed DNA methylation (RdDM) pathway. Small, non-coding RNAs (sRNAs, 19-24 nucleotides (nt) in length) play a critical role in growth, development, and stress response in both mammals and plants [22]. The 24-nt sRNAs are produced from double stranded RNA through the activities of RNA-dependent RNA polymerase 2 (RDR2) and DICER-LIKE 3 (DCL3), then bind ARGONAUTE 4 (AGO4) protein $[23,24]$ and recruit DRM2 to catalyze methylation at $\mathrm{CHH}$ sites.

Research has shown that DNA methylation regulates leaf morphology, flowering time, floral organ identity, fertility, and embryogenesis in addition to silencing TEs, repetitive sequences, and transgenes in plants [25-35]. Mutations in DNA methyltransferase MET1 and DECREASE IN DNA METHYLATION 1 (DDM1), an ATP-dependent SWI2/SNF2 chromatin-remodeling factor, also affect seed development [33,36-38], suggesting that DNA methylation is critical for seed development. $D M E$ DNA glycosylase is expressed specifically in the central cell of the female gametophyte and vegetative cell of the male gametophyte. DME-mediated DNA demethylation is essential for endosperm development in Arabidopsis.

Recent research shows that DNA methylation is dynamic during plant development. For example, DNA methylation levels in the gene promoter can change during different stages of seed maturation in soybean [39]. Furthermore, DNA methylation levels vary in different cell types in gametophytes that have the same origin and are separated only by a few cell divisions. However, the molecular mechanism regulating these dynamic DNA methylation patterns remains to be elucidated.

This review focuses on the variation of DNA methylation in different plant species, organs, tissues, and cells. The dynamics of DNA methylation are also summarized during plant growth and development as well as in response to environmental stresses. Future challenges in this area are also discussed. 


\section{Variations of DNA Methylation in Different Plant Species}

To date, DNA methylation has been studied in many plant species, ranging from algae, cereal crops, vegetables, to trees. Research shows a wide diversity of DNA methylation in terms of levels and sequence contexts (Figure 1). Among more than 30 plant species with methylome data, non-vascular unicellular Chlamydomonas reinhardtii (green algae) has the lowest DNA methylation $(5.4 \%, 2.6 \%$, and $2.5 \%$ in the contexts CG, CHG and CHH, respectively) (Figure 1) [40,41]. By contrast, land plants in general have much higher levels of DNA methylation, especially at CG and CHG contexts. For example, in Arabidopsis leaves, 30.5\%, 10.0\%, 3.9\% methylation occurs in CG, CHG, CHH sites, respectively [41]. Rice leaves have an intermediate level of DNA methylation: $58.4 \%$ of CG, 31.0\% of CHG, and $5.1 \%$ of $\mathrm{CHH}$ sites are methylated [41]. Beta vulgaris (beet) leaves have the highest DNA methylation: $92.6 \%$, $81.2 \%$, and $18.9 \%$ in CG, CHG and CHH, respectively (Figure 1) [41].

It is apparent that genome-wide DNA methylation shows extensive variation among plant species in all three DNA methylation contexts (Figure 1) [41-43]. CG methylation is the predominant type of DNA methylation compared with CHG and CHH methylation. In angiosperms, CG methylation contributes to more than 50\% of total cytosine methylation [41]. CHG and $\mathrm{CHH}$ methylation levels vary more widely than CG methylation among species. B. vulgaris has a very high percentage of $\mathrm{CHG}$ $(81.2 \%)$ and $\mathrm{CHH}$ methylation $(18.9 \%)$, while Eutrema salsugineum has the lowest CHG methylation (9.3\%) and moderate CG (38.2\%) and CHH methylation (6.1\%). Vitis vinifera has the lowest $\mathrm{CHH}$ methylation level (1.2\%) with 46.0\% CG and 20.4\% CHG methylation [41]. Species in Brassicaceae have reduced CG and CHG methylation, while CHH methylation is depleted in some species in Poaceae, which suggests that DNA methylation patterns are diverse in various species [41].

In genic regions, angiosperms and unicellular green algae have a marked dip in DNA methylation just around the transcriptional start site (TSS) and high CG methylation in most gene bodies, while gymnosperms like Selaginella moellendorffii lack DNA methylation at the TSS and gene bodies [44,45]. TEs are highly methylated in plants, and methylation is correlated with the inhibition of TEs and repeats. Components in different methylation pathways will be discussed in Section 7. 


\begin{tabular}{|c|c|c|c|c|}
\hline & & CG & CHG & $\mathrm{CHH}$ \\
\hline \multirow{5}{*}{ Metazoa } & Mus musculus (mouse) & 74.2 & 0.30 & 0.29 \\
\hline & Homo sapiens (human) & 82.7 & ND & ND \\
\hline & Tetraodon nigroviridis (puffer fish) & 65.5 & 0.25 & 0.34 \\
\hline & Danio rerio (zebrafish) & 80.3 & 1.22 & 0.91 \\
\hline & Ciona intestinalis (sea squirt) & 31.1 & 0.17 & 0.12 \\
\hline \multirow{34}{*}{ Viridiplantae } & Apis mellifera (honey bee) & 0.51 & 0.11 & 0.16 \\
\hline & Drosophila melanogaster (fruit fly) & 0.12 & 0.11 & 0.11 \\
\hline & Bombyx mori (silk moth) & 0.71 & 0.08 & 0.09 \\
\hline & Uncinocarpus reesii & 0.67 & ND & ND \\
\hline & Coprinopsis cinerea & 12.2 & ND & ND \\
\hline & Phycomyces blakesleeanus & 4.9 & ND & ND \\
\hline & Chlorella sp. NC64A & 80.5 & 2.2 & 0.25 \\
\hline & Chlamydomonas reinhardtii & 5.4 & 2.6 & 2.5 \\
\hline & Beta vulgaris (beet) & 92.6 & 81.2 & 18.9 \\
\hline & - Selaginella moellendorffii & 12.5 & 9.0 & 0.92 \\
\hline & - Vitis vinifera (grape) & 46.0 & 20.4 & 1.2 \\
\hline & - Zea mays (maize) & 86.0 & 74.0 & 5.4 \\
\hline & - Sorghum bicolor (sorghum) & 52.5 & 27.1 & 2.1 \\
\hline & - Setaria viridis & 44.5 & 23.3 & 1.6 \\
\hline & - Oryza sativa (rice) & 58.4 & 31.0 & 5.5 \\
\hline & Solanum tuberosum (potato) & 70.9 & 42.2 & 15.8 \\
\hline & - Solanum lycopersicum (tomato) & 84.1 & 54.8 & 8.4 \\
\hline & Phaseolus vulgaris (green bean) & 49.8 & 33.4 & 4.0 \\
\hline & Glycine max (soybean) & 63.2 & 38.4 & 4.1 \\
\hline & Eutrema salsugineum & 38.2 & 9.3 & 6.1 \\
\hline & Brassica oleracea (wild cabbage) & 52.6 & 22.0 & 5.1 \\
\hline & - Arabidopsis lyrata & 41.0 & 21.0 & 6.5 \\
\hline & Arabidopsis thaliana & 30.5 & 10.0 & 3.9 \\
\hline & - Manihot esculenta (cassava) & 51.5 & 30.4 & 1.9 \\
\hline & - Populus trichocarpa (California poplar) & 44.0 & 26.8 & 5.0 \\
\hline & Cucumis sativus (cucumber) & 45.9 & 16.5 & 4.1 \\
\hline & — Gossypium raimondii & 72.0 & 57.8 & 13.2 \\
\hline & — Theobroma cacao (cacao tree) & 44.1 & 15.2 & 1.5 \\
\hline & - Fragaria vesca (woodland strawberry) & 48.4 & 20.6 & 2.3 \\
\hline & - Prunus persica (peach) & 50.2 & 19.6 & 3.7 \\
\hline & L Malus $x$ domestica Borkh. (apple) & 63.5 & 44.1 & 4.6 \\
\hline & Cannabis sativa (cannabis) & 75.6 & 65.0 & 8.7 \\
\hline & Physcomitrella patens & 29.5 & 29.7 & 23.2 \\
\hline & Citrus $\times$ clementina (clementine) & 45.8 & 25.1 & 8.3 \\
\hline
\end{tabular}

Figure 1. DNA methylation levels in 39 eukaryotic organisms. Although the methylation data were from different studies, and in different organs or tissues that might have some technical variations among different experiments, all of these were from recent methylome research, and procedures and technologies used were similar, including genomic library construction, bisulfite conversion and efficiency, and next-generation sequencing. Taxonomy was obtained from the National Center for Biotechnology Information (NCBI) (https:/ / www.ncbi.nlm.nih.gov/taxonomy). Species, materials and methylation data in Figure 1 were from references listed below: M. musculus, E13.5 embryos from strain C57BL/6J [45]; H. sapiens, H1 human embryonic stem cells [46]; T. nigroviridis, whole fish [44]; D. rerio, 5-day-old embryos [45]; C. intestinalis, Ciona animals collected from Half Moon Bay, CA [45]; A. mellifera, whole adult workers [44]; D. melanogaster, embryo 0-3 h [44]; B. mori, whole larvae [44]; U. reesii, mycelium [44]; C. cinereal, mycelium of strain Okayama 7 [44]; P. blakesleeanus, mycelium of strain NRRL 1555 [44]; Chlorella sp. NC64A, cells cultured in medium [44]; C. reinhardtii, vegetative cells from strain CC503 [45]; B. vulgaris, leaf [41]; S. moellendorffii, aerial tissues of adult soil plants [44]; V. vinifera, leaf [41]; Z. mays, kernel [47]; S. bicolor, leaf [41]; S. viridis, leaf [41]; O. sativa, leaf [41]; S. tuberosum, tuber tissue [48]; S. lycopersicum, leaf [41]; P. vulgaris, leaf [41]; G. max, fully expanded leaf [39]; E. salsugineum, leaf [41]; B. oleracea, leaf [41]; A. lyrate, leaf [41]; A. thaliana, leaf [41]; M. esculenta, leaf [41]; P. trichocarpa, leaf [41]; C. sativus, leaf [41]; G. raimondii, leaf [41]; T. cacao, leaf [41]; F. vesca, leaf [41]; P. persica, leaf [41]; M. domestica, leaf [41]; C. sativa, leaf [41]; P. patens, whole plants growing on plates [44]; C. clementine, leaf [41]. ND, not determined. 


\section{DNA Methylation Profiles in Different Plant Organs and Tissues}

Previous studies showed that there is increased DNA methylation in vegetative organs, such as leaves, shoots, and roots compared with cotyledons in many species like tomato, Silene latifolia, and Arabidopsis [49-51]. Juvenile shoot apical meristem (SAM) has lower DNA methylation compared with adult SAM in peach [52]. In Arabidopsis, CG methylation levels are very similar among different tissues except for reduced methylation in endosperm although there may be some technical variations among different experiments (Figure 2) [39,53-55]. In Arabidopsis root meristem, the genome of the columella root cap is the most highly methylated cell characterized [56]. A study shows that CG and CHG methylation levels were very similar among examined organs: embryos, shoots, roots, and leaves in rice [54], but $\mathrm{CHH}$ methylation levels increased from embryos to young shoots and roots, and reaches its highest levels in mature leaves [54]. Rice endosperm compared with the embryo has lower DNA methylation in all three methylation contexts, which is the same as Arabidopsis (Figure 2) [54,55]. In soybean, the difference of DNA methylation levels in all contexts was small between any two examined vegetative organs [57].

It is not clear if or when global DNA demethylation occurs [58,59]. During development of the male sexual lineage, CG and CHG methylation are kept at high levels in meiocytes, microspores, and sperms compared with those in shoot (Figure 2), which is consistent with a previous study showing high efficiency of CG methylation in pollen (Figure 2) [60]. CHH methylation levels are reduced in the sperm cell nucleus with significant elevation in the microspores and sperms, suggesting a conflict between methylation maintenance and demethylation during the development of the male sexual lineage [58].

The difference in DNA methylation levels of various tissues is likely related to the involvement of different DNA methylation pathways. CG methylation in the loci of some sexual specific lineage is initiated by the RdDM pathway in germ line cells. However, these loci are maintained at a lower CG methylation level in the somatic cells by the MET1 rather than the RdDM pathway [58].

\begin{tabular}{|c|c|c|c|c|c|c|c|}
\hline Cell Types & CG & CHG & $\mathrm{CHH}$ & & & & \\
\hline Vegetative nucleus 1 & 29.3 & 15.0 & 5.4 & Organs & CG & CHG & $\mathrm{CHH}$ \\
\hline Vegetative nucleus 2 & 26.9 & 13.0 & 4.0 - & Inflorescence & 27.8 & 12.1 & 5.8 \\
\hline Sperm cell nuclei 1 & 31.4 & 12.3 & 1.6 & Shoot 1 & 22.3 & 5.9 & 1.5 \\
\hline Sperm cell nuclei 2 & 31.2 & 12.7 & 2.1 & $\begin{array}{l}\text { Shoot } 2 \text { (all tissues of the plant } \\
\text { growing above ground) }\end{array}$ & $\sim 21.9$ & $\sim 6.9$ & $\sim 1.8$ \\
\hline Microspore & 28.8 & 12.5 & 1.8 & Leaf 1 & 30.5 & 10.0 & 3.9 \\
\hline Tissues & CG & CHG & $\mathrm{CHH}$ & & 28.5 & 7.8 & 1.6 \\
\hline Endosperm & 20.9 & 8.9 & $2.8^{\prime}$ & Ws-O leaf & 24.5 & 5.4 & 0.8 \\
\hline Embryo 1 & 26.9 & 10.6 & 4.4 & Rosette leaf 1 & 32.8 & 15.7 & 4.6 \\
\hline Embryo 2 & 27.5 & 10.7 & 4.5 & Rosette leaf 2 & 22.1 & 6.4 & 2.0 \\
\hline Organs & CG & CHG & $\mathrm{CHH}$ & Root (one-month-ọld) & $\sim 21.6$ & $\sim 6.5$ & $\sim 1.8$ \\
\hline $\mathrm{Col}-\mathrm{O}$ postmature green seed & 25.0 & 8.5 & 2.7 & $\begin{array}{l}\text { Whole plant (Five-week-old } \\
\text { continuous light-grown) }\end{array}$ & 24.0 & 6.7 & 1.7 \\
\hline Col-O dry seed & 25.9 & 8.5 & 2.9 & & & & \\
\hline Ws- $O$ seed at globular stage & 23.8 & 8.0 & 0.9 & & & & \\
\hline Ws- $O$ postmature green seed & 24.3 & 7.8 & 1.8 & & & & \\
\hline Ws- $O$ dry seed & 25.2 & 8.4 & 2.1 & & & & \\
\hline
\end{tabular}

Figure 2. DNA methylation levels in different organs, tissues, and cells in Arabidopsis. Organs, tissues, or cell types were collected from wild type Col-O (Columbia) except the organs indicated as Ws-0, referring to Wassilewskija. Organs, tissues, cells, and methylation data were from references listed below: vegetative nucleus 1, sperm cell nuclei 1, microspore, embryo 2, and inflorescence [61]; vegetative nucleus 2 and sperm cell nuclei 2 [62]; endosperm and embryo 1 [55]; postmature green seed, dry seed, leaf 2, Ws-0 seed and leaf [63]; leaf 1 [41]; rosette leaf 1 [64]; Rosette leaf 2 [65]; shoot 1 [45]; shoot 2 and root [53]; whole plant [66]. The methylation data were from different studies that might have some technical variations among different experiments, but procedures and technologies (genomic library construction, bisulfite conversion and efficiency, and next-generation sequencing) used were similar, thus overall results can be compared. 


\section{Reprogramming of DNA Methylation in Gametogenesis}

It is controversial whether plants have a segregated germline or when the germline is differentiated during development [67]. Regardless whether a germline in a plant species is set aside early or late during development, the first germline cell likely inherits most of its epigenetic profile from the somatic parent plant. When a megaspore mother cell undergoes meiosis to form four haploid megaspores, one of the four spores develops into a haploid female gametophyte. Recent research clearly indicates that DNA methylation profiles in different cell types of the female gametogenesis undergo reprograming or dynamic changes that results in DNA methylome different from the somatic parental cells [62].

Genomic imprinting refers to differential expression of parental alleles. The central cell is fertilized by a sperm to form the endosperm where most of genomic imprinting occurs. MEDEA (MEA), FERTILIZATION INDEPENDENT ENDOSPERM (FIE), FERTILIZATION INDEPENDENT SEED 2 (FIS2), and FLOWERING WAGENINGEN (FWA) are the first few set of genes that were identified to be maternally expressed imprinted genes [35,68-70]. Their methylation status undergoes dynamic changes: methylation of the maternal allele was maintained by MET1 before differentiation of the central cell, and then demethylated by DME in the central cell, resulting in hypomethylation whereas the paternal allele of those genes was methylated by DNA methyltransferases in the male gametophyte. The maternal allele of a gene demethylated by DME in the central cell, and the maternal MET1 allele is repressed by Polycomb Repressive Complex 2 (PRC2) [71,72], thus the maternal allele is hypomethylated and silenced. The maternal MEA, FIE, FIS2, and FWA allele expression in the Arabidopsis central cell and endosperm is antagonistically regulated by DME and MET1 [26,34,35,69,70]. Some maternal hypomethylated TEs due to DME activity can result in expression of small RNA in the endosperm, which is hypothesized to be transported to the embryo to methylate the homologous TEs or nearby genes through the RdDM pathway, reinforcing gene silencing in the embryo [62]. The maternally expressed in embryo 1 (mee1) in maize, is imprinted in both the embryo and endosperm [73]. The embryonic maternal mee 1 is demethylated on fertilization and remethylated during embryogenesis. However, the maternal mee1 remains hypomethylated in the endosperm [73]. It remains unknown which mechanism causes the maternal demethylation in early embryo. One speculation is whether siRNA generated from the hypomethylated maternal allele in endosperm can mediate recruitment of DME to the maternal mee1 allele in early embryo.

Epigenetic changes or reprogramming during male gametogenesis result in different epigenetic profiles in gametes compared with a microspore mother cell or its somatic parental cells. In the male gametophyte, $D M E$ is specifically expressed in the vegetative cell instead of the sperm cell. $D M E$ expression is limited in late bicellular stage pollen and reduced to undetectable level as pollen matures [74]. Thus, CG methylation in imprinted genes or DME-targets is lost in the vegetative nucleus. Expression of siRNA from hypomethylated TEs in the vegetative nucleus is likely to move from the vegetative nucleus to the sperm cell to reinforce silencing of TEs in the sperm cell which passes its genetic information to the next generation $[61,62,75]$. CHH methylation in TEs is lost in microspores and sperm nuclei but is restored by 24 -nt small RNA in both the vegetative nucleus and fertilized embryo (Figure 2) [61]. Furthermore, epigenetically activated siRNAs from the paternal genome can regulate parental genome dosage and seed viability [76]. Thus, reprogramming of DNA methylation in the male gametophyte (vegetative and sperm cells) and the female gametophyte (the central cell and egg cells) through DNA methyltransferases, demethylases and small RNA is part of the epigenetic mechanisms to maintain overall inheritance of phenotypes to the next generation. It is worth mentioning that not all imprinted genes are a byproduct of epigenetic reprogramming in gametes and seed. Studying imprinting in Arabidopsis lyrata shows that the maternal allele of many paternally expressed imprinted gene (PEGs) was hypermethylated in CHG, and this increased CHG hypermethylation was correlated with increased expression bias in favor of the paternal allele, suggesting that CHG methylation in the maternal allele of PEGs reinforces the silencing of the maternal allele [77]. 


\section{Dynamic DNA Methylation during Seed Development and Germination}

Seed development is vital for seed quality and yield. Research has shown that DNA methylation changes during seed development. During soybean seed development, DNA methylation in the $\mathrm{CHH}$ context increased from $6 \%$ at the early stage to $11 \%$ in the late stage [39]. In soybean, a total of 2136 genes contain differentially methylated regions (DMRs) with a negative correlation between gene expression and $\mathrm{CHH}$ methylation levels in promoters [39]. Another study that profiled both soybean and Arabidopsis methylomes from the globular stage through dormancy and germination also showed that $\mathrm{CHH}$ methylation increases significantly during seed development while no significant changes occurred for methylation in CG and CHG context [63]. To gain further insights on whether $\mathrm{CHH}$ methylation does regulate seed development, Lin et al. examined the Arabidopsis drm 1 drm $2 \mathrm{cmt} 2 \mathrm{cmt} 3$ mutant $(d d c c)$ that is deficient in methyltransferases required for non-CG methylation [63]. Surprisingly seed development, germination, and seed gene activity seem normal in this mutant, suggesting that $\mathrm{CHG}$ and $\mathrm{CHH}$ methylation might not play a significant role in seed development or in regulating seed gene activity in Arabidopsis even though $\mathrm{CHH}$ methylation levels increase as the seed develops. However, the authors did find that more than 100 TEs are transcriptionally de-repressed in $d d c c$ seeds, implying that $\mathrm{CHG}$ and $\mathrm{CHH}$ methylation could simply be a mechanism to reinforce TE silencing [63]. To further investigate the role of DNA methylation for seed development and germination, they looked at the methylation landscapes of 75 genes important for seed development and germination. Unexpectedly, they found that half of the genes are located in genomic regions with undetectable or no methylation known as demethylated valleys (DMVs) [63]. The very low or no methylation status of DMVs did not change from fertilization to germination [63]. Another study agrees with these findings that DNA hypomethylation does not appear to be a major mechanism of gene regulation during germination but could affect the expression of a specific set of genes. The conclusion was based on the fact that most $\mathrm{CHH}$ DMRs did not have a complete removal of methylation but a gradual reduction in methylation. This gradual reduction of methylation was viewed as passive DNA demethylation [78].

Hypermethylation could be related to a halt in transcription as dry seeds enter dormancy $[79,80]$. Examining expression of genes involved in the DNA methylation and demethylation pathways shows that ROS1, DEMETER-LIKE 2 and 3 (DML2 and DML3) are not involved in global demethylation, and demethylation occurs in a passive manner by dilution of methylation because of increased cell division [79]. During Arabidopsis seed maturation, nuclear size is reduced and nuclei are highly condensed in seeds while the opposite is observed during germination-nuclei regain their size and chromatin is decondensed [81]. It is likely that DNA methylation is involved in chromatin condensation and decondensation during seed maturation and germination, respectively. In rice seed development, the highest levels of methylation were reached in the endosperm at 2 days after pollination (DAP), when cellularization and genome-wide demethylation began, resulting in increased expression of demethylated genes [82]. This suggests that endosperm cellularization could be regulated by dynamic methylation. Additionally, 25 genes show differential methylation during rice seed development [82]. More significantly, recent research in Brassica rapa clearly shows that DNA methylation is required for seed development [83]. Mutations in Pol IV-mediated small RNA pathway result in defects in reproduction of Brassica rapa. Furthermore, The RdDM pathway is crucial in maternal somatic tissues, not in the female gametophyte or zygote [83]. This suggests that different plant species might have different sensitivity or tolerance to loss or interruption of DNA methylation.

\section{Alteration of DNA Methylation in Response to Environmental Stimuli}

DNA methylation is involved in plant response to environmental stresses. By whole-genome bisulfite sequencing of single-cell root hairs and multicellular stripped roots in response to heat stress in soybean, it was found that both samples showed hypomethylation after stress. Although the differences between the control and stressed samples were marginal (less than 10\%) among CG and CHG, $\mathrm{CHH}$ methylation in stressed samples decreased significantly by $25 \%$ and $37 \%$ in genes and TEs, respectively [84]. When compared to wild-type plants, the mutant of $d d m 1$ plants had shorter roots 
and lower survivability during salt stress [85]. This could be due to the alteration of expression of transcription factors since they have been shown to play an important role in gene activation during salt stress [86]. AtMYB74, a transcription factor of the R2R3-MYB gene family, had a significant increase in the mRNA level in response to salt treatment, and levels of DNA methylation were significantly reduced in the AtMYB74 promoter. Expression of $A t M Y B 74$ and its promoter methylation is regulated by the 24-nt siRNAs-mediated RdDM pathway during salt stress [86]. Evidence that epigenetics plays a role in salt tolerance extends to the Arabidopsis H3K4 demethylase gene JMJ15. Gain-of-function mutants showed enhanced salt tolerance and loss-of-function mutants were more sensitive to salt [87]. Plants under a mild drought stress accumulated drought-associated epialleles, but the epialleles were not correlated with gene expression of drought-responsive genes [65]. Under transgenerational drought stress, negligible conserved differentially methylated regions (DMRs) were observed in drought-exposed lineages compared with control plants, suggesting that DNA methylome is relatively stable under drought stress [65].

DNA methylation has been linked to plant immune response $[88,89]$. Studying DNA methylation in response to different virulent factors showed that mutants with reduction of cytosine methylation (met1 and drm1 drm $2 \mathrm{cmt} 3(d d c)$ ) were more resistant to Pseudomonas syringae pv tomato DC3000 (PstDC3000) infection [90]. Expression of many pathogen-responsive genes was altered in the mutants. These data suggest that certain genes were repressed by DNA methylation in non-affected tissues, but upon infection by pathogens, methylation could be changed to adapt to stress condition. Methylation in the CG and CHG contexts was altered similarly but methylation in the $\mathrm{CHH}$ context varied when exposed to different pathogens, suggesting that different pathogens can cause distinct changes of $\mathrm{CHH}$ methylation levels.

Although methylation profiles can change in response to biotic stresses such as pathogen attack, whether alteration of DNA methylation can allow plants to prime their descendants for disease-resistance transcriptional changes needs to be substantiated [91]. By comparing the progeny of Arabidopsis treated with PstDC3000 and control plants, the PstDC3000-treated Arabidopsis had progeny that were primed to activate the salicylic acid-inducible defense genes and were more resistant to the pathogen Hyaloperonoospora arabidopsis (Hpa) and PstDC3000 [92]. The $d d c$ mutant had progeny that mimicked the resistance, suggesting that DNA hypomethylation and non-CG methylation might serve as the transmitter of immunity to the next generation in plants. Recently it has been shown that DNA methylation and DNA demethylation can have opposite effects on basal resistance to Hpa [93]. Several hypo-methylated mutants including nrpe1 (nuclear RNA polymerase E1) displayed enhanced resistance to $\mathrm{Hpa}$ while two hyper-methylated mutants including ros1 were more susceptible to the pathogen. It is exciting to see this emerging evidence that priming can alter plant epigenetic profiles and potentially improve plant resistance to stresses especially biotic stress. However, occurrence and inheritance of such an epiallele that allows plants transgenerational priming are usually a very rare sporadic event [91,94,95]. Mechanistically an epiallele can be generated through the movement of TEs and altered DNA methylation patterns via the RdDM pathway, or an epigenetic byproduct of an aggressive germline defense strategy. To utilize these epialleles to benefit agriculture in genetics and breeding will remain challenging because it is very unlikely these induced epigenetic alterations in response to environmental stresses are transgenerationally inherited.

\section{Mechanisms of Dynamic DNA Methylation}

Cytosine methylation is an ancient modification that is required to maintain genomic structure and stability in many eukaryotes. In plants, DNA methylation has been found to silence TEs and repeats as well as regulate gene expression. Animals have a separate germ line where DNA methylation patterns are erased and reestablished. It has been debatable whether plants have a segregated germline established early in development [67], but most plants are thought to set aside a germline cell (megaspore or microspore mother cells) late in development and there is no genome-wide erasure and reestablishment during gametogenesis in plants, meaning that epigenetic changes induced in parents 
can be inherited and maintained in progenies [96]. This might allow plants to find a balance between keeping epigenetic patterns stable to avoid detrimental effects on genome structures and keeping those epigenetic patterns sufficiently flexible to induce epigenetic variation required for quick adaptation to new environmental conditions [97]. These dynamic methylation patterns depend on the coordination of many plant-specific methyltransferases and demethylases.

$M E A$, a SET domain Polycomb group gene, was the first plant gene to be identified as imprinted in the endosperm. MET1 is responsible for maintaining methylation at the MEA promoter, and DME DNA glycosylase antagonistically excises 5-methylcytosine at the maternal MEA allele through the BER pathway [34]. Mutations in ROS1 cause transcriptional gene silencing of transgenes [98]. Active DNA demethylation by DME and ROS1 prevents accumulation of 5-methylcytosines at genes. Interestingly, ROS1 expression is induced by DNA methylation and suppressed by DNA demethylation [99]. Induced methylation in the ROS1 proximal region can restore ROS1 expression in an RdDM mutant. It was suggested that ROS1 functions as an epigenetic rheostat to maintain epigenome stability by adjusting ROS1 demethylase activity in response to methylation changes $[99,100]$.

The RdDM pathway is a major mechanism for cytosine methylation in euchromatic TEs in Arabidopsis and maize. RdDM is initiated by the transcription of non-coding single-stranded RNAs (ssRNAs) by a plant-specific RNA polymerase, RNA Pol IV. Then, these non-coding ssRNAs are used to synthesize double-stranded RNAs (dsRNAs) by RNA-dependent RNA polymerase 2 (RDR2). Afterwards, DICER-LIKE 3 (DCL3) will process the dsRNA [54] into 24-nucleotide siRNAs, which are then methylated at their $3^{\prime}$-OH by HUA ENCHANCER 1 (HEN1) and loaded onto ARGONAUTE 4 (AGO4) [101]. Pol V recruits AGO4 through the C-terminal domain of Pol V's largest subunit, NRPE1, which is able to interact with the KOW DOMAIN-CONTAINING TRANSCRIPTION FACTOR 1 (KTF1), a transcription factor that contains an AGO hook motif [102-104]. Recently it has been shown that CLASSY (CLSY) 1-4, SNF2-related, putative chromatin remodeling factors, are required for locus-specific and global DNA methylation in Arabidopsis [105]. The CLSY family controls 24-nt-siRNA production and is crucial for Pol IV chromatin association [105]. Finally, the AGO4-bound siRNA is proposed to pair complementarily with the Pol V transcript and recruit DRM2 to catalyze de novo methylation at homologous genomic sites.

The RdDM pathway has been shown to transcriptionally repress TEs and alter gene expression that is partially involved in pathogen defense, stress responses, development, and intercellular communication. While there has been no obvious fertility defect associated with loss of RdDM in Arabidopsis, the maize ago9 mutant failed to complete meiosis and generate functional gametes [106]. The RdDM pathway regulates parental gene imprinting at several loci in Arabidopsis [107]. Furthermore, the maternal allele of components in the RdDM pathway is required for seed development in Brassica rapa [83]. The RdDM pathway has also been shown to respond to environmental changes, which in turn triggers epigenetic changes at particular loci to generate heritable epialleles in the next generation $[108,109]$. In short, the RdDM pathway might represent a form of epigenetic adaptive inheritance that could offer fitness advantage to descendants after a plant encounters a particularly stressful environment [92,110].

\section{Conclusions and Discussion}

Since the first eukaryotic DNA methylome was sequenced in base-pair resolution in Arabidopsis 10 years ago [66,111], DNA methylomes of more than 50 organisms have been sequenced including many plant species, which greatly increases our knowledge about DNA methylomes. In angiosperms, genome-wide DNA methylation levels are thought to be correlated with genome size for CG and CHG, but not for $\mathrm{CHH}$. However, after removing DNA methylome data of Z. Mays (the largest genome with the whole methylome data), only genome-wide CHG methylation levels remain correlated with genome size [41], while CG and CHH methylation show no correlation with genome size. This seems counterintuitive since CG are highly methylated in repetitive sequences that usually increase as genome size increases. Alternatively, it can be due to difference of GC contents in a genome, 
or particular regions in the genome, and/or chromatin structure such as histone variant H2A.Z distribution $[44,112]$. Studies have revealed a wide variation of DNA methylation among different species, organs, tissues, and cells. Existing hypotheses such as correlation between genome size and genome-wide DNA methylation levels, GC contents, and chromatin structure cannot fully explain why there is such a big variation of DNA methylation among different species. For example, C. elegans has no DNA methylation, Drosophila melanogaster has very low or no detectable methylation, some fungi have relatively low methylation, and angiosperms and mammals have relatively high methylation. There are also no consistent patterns in terms of DNA methylation in genes, TEs, and repeats among different organisms. Having said the above, DNA methylation seems to be an ancient part of speciation during eukaryotic evolution or at least an integral part of historical, natural variations in forming different species [40-42,44,113].

Although overall DNA methylation is quite diverse among species, it occurs in the CG, CHG, $\mathrm{CHH}$ contexts of gene bodies, TEs and repeats in most plants. The Brassicaceae have reduced CHG methylation and reduced or no CG body methylation [41]. The Poaceae have reduced or no $\mathrm{CHH}$ methylation in heterochromatin but increased $\mathrm{CHH}$ methylation in genic regions [41]. In general, moderately highly expressed genes (e.g., 70th transcription percentile in Arabidopsis and rice) are most methylated in the gene body [44]. DNA methylation dips significantly just upstream of the transcriptional start site (TSS) and around the transcriptional termination site (TTS). Low methylation in the promoter is correlated with increased expression for some genes in Arabidopsis, soybean, and rice [39]. Three basal plant species Selaginella moellendorffii, Physcomitrella patterns, and Marchantia polymorpha have little methylation or virtually no methylation in gene bodies and around the TSS, but methylation is found in TEs and repeats [44]. This suggests DNA methylation is not part of gene regulation although it may still function to silence TEs and repeats in these diverging land plants. The green alga Chamydomonas has an unusual DNA methylation pattern: having relatively high CHG and CHH methylation in gene exons rather than in TEs and repeats [40]. In the angiosperms, DNA methylation functions as an epigenetic mechanism in regulating gene expression in addition to silencing TEs and repeats.

The function of high methylation levels in TEs is to silence the TEs in most plant species. CG methylation is extremely high (mostly higher than $80 \%$ ) in repeats across all angiosperms, while CHG and CHH methylation varies among species [39-41,44,63]. CHG methylation is relatively high, and varies among most angiosperms from $15.2 \%$ to $81.2 \%$ with the exception of the lowest $(9.3 \%)$ in Brassicaceae. The amount of $\mathrm{CHH}$ methylation is low, and the lowest levels $(1.2 \%)$ are found in most Poaceae [41]. Genome-wide methylation levels in the CG and CHG contexts are correlated with the proliferation of repeat sequences while $\mathrm{CHH}$ methylation is not [41]. It seems that methylation in TEs and repeats is conserved among plants. When horizontal gene transfer occurs among species, a gene duplication event or a whole genome duplication event (e.g., from diploid Arabidopsis thaliana to tetraploid Arabidopsis lyrata), DNA methylation is involved to methylate and silence the newly duplicated gene or fragments [114]. Occasionally, hypomethylation in the duplicated genes can also occur. Thus, it is likely that DNA methylation divergence in different angiosperms affects gene expression and eventually becomes part of epigenome diversity during evolution.

During eukaryotic evolution it seems that DNA methylation existed very early, perhaps in the common ancestor before fungi, plants, and animals diverged [44]. DNA methylation then follows a complex pathway to evolve in different species. The main driving force of DNA methylation is to limit proliferation following expansion and contraction of TEs. During the process of serving as TE surveillance, it occasionally evolves as an epigenetic gene regulation. For example, maize is a species that has the largest genome among sequenced methylome. Despite its large genome size, the majority of genes are associated with TEs, which are natural targets of DNA methylation. This explains why there are such high levels of methylation in maize $(86 \%, 74 \%$, and $5 \%$ in $\mathrm{CG}, \mathrm{CHG}$, and $\mathrm{CHH}$, respectively). It is possible that these methylation sites in TEs eventually became an integral part of gene regulation in some specific tissues or cells after millions of years of evolution. DNA methylation can 
be altered by different environmental stimuli, such as pathogens and abiotic stresses. These dynamic temporary methylation changes might not be preserved during evolution unless plants encounter a constant selection pressure [113]. Different plant species do not have the same or similar DNA methylation patterns because they possess different sets of DNA methyltransferases (MET1, CMT2, CMT3, DRM1, and DRM2) and demethylases (DME, ROS1, DML2 and DML3). Of course, the RdDM pathway provides another mechanism to methylate and then silence TEs, repeats, and genes. In conclusion, DNA methylation patterns in angiosperms are complex, dynamic, and an integral part of the epigenome during evolution.

Author Contributions: Conceived and designed the work: W.X.; Acquired and analyzed the data: A.B., Q.H., P.N., L.S., H.G., M.M., Q.Q.H., J.K.P., T.-F.H., Y.-Q.C.A., W.X.; Wrote the manuscript: A.B., Q.H., W.X.

Acknowledgments: This work was supported by a National Science Foundation grant (Project \#: 1715115) to T.-F.H. and W.X.

Conflicts of Interest: The authors declare no conflict of interest.

\begin{tabular}{ll} 
Abbreviations \\
5mC & 5-methylcytosine \\
AGO & ARGONAUTE \\
CLSY1-4 & CLASSY1-4 \\
CMT2 & CHROMOMETHYLASE 2 \\
CMT3 & CHROMOMETHYLASE 3 \\
DCL & DICER-LIKE \\
ddc & the drm1 drm 2 cmt3 mutant \\
ddcc & the rrm1 drm2 cmt2 cmt3 mutant \\
DME & DEMETER \\
DML2 & DEMETER-LIKE 2 \\
DML3 & DEMETER-LIKE 3 \\
Dnmt1 & DNA methyltransferase 1 \\
DRM1 & DOMAINS REARRANGED METHYLTRANSFERASE 1 \\
DRM2 & DOMAINS REARRANGED METHYLTRANSFERASE 2 \\
KTF1 & KOW DOMAIN-CONTAINING TRANSCRIPTION FACTOR 1 \\
MEG & maternally expressed imprinted gene \\
MET1 & DNA METHYLTRANSFERASE 1 in plants \\
NRPE1 & NUCLEAR RNA POLYMERASE E1 \\
PcG & Polycomb group proteins \\
PEG & paternally expressed imprinted gene \\
RdDM & RNA-directed DNA methylation \\
RDR & RNA-dependent RNA polymerase \\
ROS1 & REPRESSOR OF SILENCING 1 \\
siRNA & small interference RNA \\
TET & Ten-eleven-translocation enzyme \\
TSS & transcriptional start site \\
TTS & transcriptional termination site \\
& \\
\hline
\end{tabular}

\section{References}

1. Bird, A. DNA methylation patterns and epigenetic memory. Genes Dev. 2002, 16, 6-21. [CrossRef] [PubMed]

2. Martienssen, R.A.; Colot, V. DNA methylation and epigenetic inheritance in plants and filamentous fungi. Science 2001, 293, 1070-1074. [CrossRef] [PubMed]

3. Finnegan, E.J.; Peacock, W.J.; Dennis, E.S. DNA methylation, a key regulator of plant development and other processes. Curr. Opin. Genet. Dev. 2000, 10, 217-223. [CrossRef]

4. Richards, E.J. Inherited epigenetic variation-Revisiting soft inheritance. Nat. Rev. Genet. 2006, 7, $395-401$. [CrossRef] [PubMed] 
5. Li, E. Chromatin Modification and Epigenetic Reprogramming in Mammalian Development. Nat. Rev. Genet. 2002, 3, 662-673. [CrossRef] [PubMed]

6. Li, E.; Bestor, T.H.; Jaenisch, R. Targeted mutation of the DNA methyltransferase gene results in embryonic lethality. Cell 1992, 69, 915-926. [CrossRef]

7. Vongs, A.; Kakutani, T.; Martienssen, R.A.; Richards, E.J. Arabidopsis thaliana DNA methylation mutants. Science 1993, 260, 1926-1928. [CrossRef] [PubMed]

8. Finnegan, E.J.; Dennis, E.S. Isolation and identification by sequence homology of a putative cytosine methyltransferase from Arabidopsis thaliana. Nucleic Acids Res. 1993, 21, 2383-2388. [CrossRef] [PubMed]

9. Finnegan, E.J.; Kovac, K.A. Plant DNA Methyltransferases. Plant Mol. Biol. 2000, 43, 189-201. [CrossRef] [PubMed]

10. Kankel, M.W.; Ramsey, D.E.; Stokes, T.L.; Flowers, S.K.; Haag, J.R.; Jeddeloh, J.A.; Riddle, N.C.; Verbsky, M.L.; Richards, E.J. Arabidopsis MET1 Cytosine Methyltransferase Mutants. Genetics 2003, 163, 1109-1122. [PubMed]

11. Lindroth, A.M.; Cao, X.; Jackson, J.P.; Zilberman, D.; McCallum, C.M.; Henikoff, S.; Jacobsen, S.E. Requirement of CHROMOMETHYLASE3 for maintenance of CpXpG methylation. Science 2001, 292, 2077-2080. [CrossRef] [PubMed]

12. Bartee, L.; Malagnac, F.; Bender, J. Arabidopsis CMT3 chromomethylase mutations block non-CG methylation and silencing of an endogenous gene. Genes Dev. 2001, 15, 1753-1758. [CrossRef] [PubMed]

13. Zemach, A.; Kim, M.Y.; Hsieh, P.H.; Coleman-Derr, D.; Eshed-Williams, L.; Thao, K.; Harmer, S.L.; Zilberman, D. The Arabidopsis nucleosome remodeler DDM1 allows DNA methyltransferases to access H1-containing heterochromatin. Cell 2013, 153, 193-205. [CrossRef] [PubMed]

14. Cao, X.; Jacobsen, S.E. Locus-specific control of asymmetric and CpNpG methylation by the DRM and CMT3 methyltransferase genes. Proc. Natl. Acad. Sci. USA 2002, 99, 16491-16498. [CrossRef] [PubMed]

15. Zhang, X.; Jacobsen, S.E. Genetic analyses of DNA methyltransferases in Arabidopsis thaliana. Cold Spring Harb. Symp. Quant. Biol. 2006, 71, 439-447. [CrossRef] [PubMed]

16. Teerawanichpan, P.; Krittanai, P.; Chauvatcharin, N.; Narangajavana, J. Purification and characterization of rice DNA methyltransferase. Plant Physiol. Biochem. 2009, 47, 671-680. [CrossRef] [PubMed]

17. Pradhan, S.; Cummings, M.; Roberts, R.J.; Adams, R.L. Isolation, characterization and baculovirus-mediated expression of the cDNA encoding cytosine DNA methyltransferase from Pisum sativum. Nucleic Acids Res. 1998, 26, 1214-1222. [CrossRef] [PubMed]

18. Steward, N.; Kusano, T.; Sano, H. Expression of ZmMET1, a gene encoding a DNA methyltransferase from maize, is associated not only with DNA replication in actively proliferating cells, but also with altered DNA methylation status in cold-stressed quiescent cells. Nucleic Acids Res. 2000, 28, 3250-3259. [CrossRef] [PubMed]

19. Fujimoto, R.; Sasaki, T.; Nishio, T. Characterization of DNA methyltransferase genes in Brassica rapa. Genes Genet. Syst. 2006, 81, 235-242. [CrossRef] [PubMed]

20. Papa, C.M.; Springer, N.M.; Muszynski, M.G.; Meeley, R.; Kaeppler, S.M. Maize chromomethylase Zea methyltransferase2 is required for CpNpG methylation. Plant Cell 2001, 13, 1919-1928. [CrossRef] [PubMed]

21. Pavlopoulou, A.; Kossida, S. Plant cytosine-5 DNA methyltransferases: Structure, function, and molecular evolution. Genomics 2007, 90, 530-541. [CrossRef] [PubMed]

22. Chen, X. Small RNAs in development-Insights from plants. Curr. Opin. Genet. Dev. 2012, 22, 361-367. [CrossRef] [PubMed]

23. Mallory, A.C.; Elmayan, T.; Vaucheret, H. MicroRNA maturation and action-The expanding roles of ARGONAUTEs. Curr. Opin. Plant Biol. 2008, 11, 560-566. [CrossRef] [PubMed]

24. Xie, Z.; Allen, E.; Wilken, A.; Carrington, J.C. DICER-LIKE 4 functions in trans-acting small interfering RNA biogenesis and vegetative phase change in Arabidopsis thaliana. Proc. Natl. Acad. Sci. USA 2005, 102, 12984-12989. [CrossRef] [PubMed]

25. Finnegan, E.J.; Peacock, W.J.; Dennis, E.S. Reduced DNA methylation in Arabidopsis results in abnormal plant development. Proc. Natl. Acad. Sci. USA 1996, 93, 8449-8454. [CrossRef] [PubMed]

26. Xiao, W.; Gehring, M.; Choi, Y.; Margossian, L.; Pu, H.; Harada, J.J.; Goldberg, R.B.; Pennell, R.I.; Fischer, R.L. Imprinting of the MEA Polycomb gene is controlled by antagonism between MET1 methyltransferase and DME glycosylase. Dev. Cell 2003, 5, 891-901. [CrossRef] 
27. Xiao, W.; Custard, K.D.; Brown, R.C.; Lemmon, B.E.; Harada, J.J.; Goldberg, R.B.; Fischer, R.L. DNA methylation is critical for Arabidopsis embryogenesis and seed viability. Plant Cell 2006, 18, 805-814. [CrossRef] [PubMed]

28. Rea, M.; Zheng, W.; Chen, M.; Braud, C.; Bhangu, D.; Rognan, T.N.; Xiao, W. Histone H1 affects gene imprinting and DNA methylation in Arabidopsis. Plant J. 2012, 71, 776-786. [CrossRef] [PubMed]

29. Kakutani, T.; Jeddeloh, J.A.; Flowers, S.K.; Munakata, K.; Richards, E.J. Developmental abnormalities and epimutations associated with DNA hypomethylation mutations. Proc. Natl. Acad. Sci. USA 1996, 93, 12406-12411. [CrossRef] [PubMed]

30. Jacobsen, S.E.; Sakai, H.; Finnegan, E.J.; Cao, X.; Meyerowitz, E.M. Ectopic hypermethylation of flower-specific genes in Arabidopsis. Curr. Biol. 2000, 10, 179-186. [CrossRef]

31. Miura, A.; Yonebayashi, S.; Watanabe, K.; Toyama, T.; Shimada, H.; Kakutani, T. Mobilization of transposons by a mutation abolishing full DNA methylation in Arabidopsis. Nature 2001, 411, 212-214. [CrossRef] [PubMed]

32. Butenko, Y.; Ohad, N. Polycomb-group mediated epigenetic mechanisms through plant evolution. Biochim. Biophys. Acta 2011, 1809, 395-406. [CrossRef] [PubMed]

33. Kim, M.; Ohr, H.; Lee, J.W.; Hyun, Y.; Fischer, R.L.; Choi, Y. Temporal and spatial downregulation of Arabidopsis MET1 activity results in global DNA hypomethylation and developmental defects. Mol. Cells 2008, 26, 611-615. [PubMed]

34. Choi, Y.; Gehring, M.; Johnson, L.; Hannon, M.; Harada, J.J.; Goldberg, R.B.; Jacobsen, S.E.; Fischer, R.L. DEMETER, a DNA Glycosylase Domain Protein, Is Required for Endosperm Gene Imprinting and Seed Viability in Arabidopsis. Cell 2002, 110, 33-42. [CrossRef]

35. Jullien, P.E.; Katz, A.; Oliva, M.; Ohad, N.; Berger, F. Polycomb group complexes self-regulate imprinting of the Polycomb group gene MEDEA in Arabidopsis. Curr. Biol. 2006, 16, 486-492. [CrossRef] [PubMed]

36. Xiao, W.; Brown, R.C.; Lemmon, B.E.; Harada, J.J.; Goldberg, R.B.; Fischer, R.L. Regulation of seed size by hypomethylation of maternal and paternal genomes. Plant Physiol. 2006, 142, 1160-1168. [CrossRef] [PubMed]

37. Adams, S.; Vinkenoog, R.; Spielman, M.; Dickinson, H.G.; Scott, R.J. Parent-of-origin effects on seed development in Arabidopsis thaliana require DNA methylation. Development 2000, 127, 2493-2502. [PubMed]

38. Luo, M.; Bilodeau, P.; Dennis, E.S.; Peacock, W.J.; Chaudhury, A. Expression and parent-of-origin effects for FIS2, MEA, and FIE in the endosperm and embryo of developing Arabidopsis seeds. Proc. Natl. Acad. Sci. USA 2000, 97, 10637-10642. [CrossRef] [PubMed]

39. An, Y.C.; Goettel, W.; Han, Q.; Bartels, A.; Liu, Z.; Xiao, W. Dynamic Changes of Genome-Wide DNA Methylation during Soybean Seed Development. Sci. Rep. 2017, 7, 12263. [CrossRef] [PubMed]

40. Feng, S.; Jacobsen, S.E.; Reik, W. Epigenetic reprogramming in plant and animal development. Science 2010, 330, 622-627. [CrossRef] [PubMed]

41. Niederhuth, C.E.; Bewick, A.J.; Ji, L.; Alabady, M.S.; Kim, K.D.; Li, Q.; Rohr, N.A.; Rambani, A.; Burke, J.M.; Udall, J.A.; et al. Widespread natural variation of DNA methylation within angiosperms. Genome Biol. 2016, 17, 194. [CrossRef] [PubMed]

42. Takuno, S.; Ran, J.H.; Gaut, B.S. Evolutionary patterns of genic DNA methylation vary across land plants. Nat. Plants 2016, 2, 15222. [CrossRef] [PubMed]

43. Alonso, C.; Perez, R.; Bazaga, P.; Herrera, C.M. Global DNA cytosine methylation as an evolving trait: Phylogenetic signal and correlated evolution with genome size in angiosperms. Front. Genet. 2015, 6, 4. [CrossRef] [PubMed]

44. Zemach, A.; McDaniel, I.E.; Silva, P.; Zilberman, D. Genome-wide evolutionary analysis of eukaryotic DNA methylation. Science 2010, 328, 916-919. [CrossRef] [PubMed]

45. Feng, S.; Cokus, S.J.; Zhang, X.; Chen, P.Y.; Bostick, M.; Goll, M.G.; Hetzel, J.; Jain, J.; Strauss, S.H.; Halpern, M.E.; et al. Conservation and divergence of methylation patterning in plants and animals. Proc. Natl. Acad. Sci. USA 2010, 107, 8689-8694. [CrossRef] [PubMed]

46. Lister, R.; Pelizzola, M.; Dowen, R.H.; Hawkins, R.D.; Hon, G.; Tonti-Filippini, J.; Nery, J.R.; Lee, L.; Ye, Z.; Ngo, Q.M.; et al. Human DNA methylomes at base resolution show widespread epigenomic differences. Nature 2009, 462, 315-322. [CrossRef] [PubMed]

47. Gent, J.I.; Ellis, N.A.; Guo, L.; Harkess, A.E.; Yao, Y.; Zhang, X.; Dawe, R.K. CHH islands: De novo DNA methylation in near-gene chromatin regulation in maize. Genome Res. 2013, 23, 628-637. [CrossRef] [PubMed] 
48. Wang, L.; Xie, J.; Hu, J.; Lan, B.; You, C.; Li, F.; Wang, Z.; Wang, H. Comparative epigenomics reveals evolution of duplicated genes in potato and tomato. Plant J. 2018, 93, 460-471. [CrossRef] [PubMed]

49. Messeguer, R.; Ganal, M.W.; Steffens, J.C.; Tanksley, S.D. Characterization of the level, target sites and inheritance of cytosine methylation in tomato nuclear DNA. Plant Mol. Biol. 1991, 16, 753-770. [CrossRef] [PubMed]

50. Ruiz-Garcia, L.; Cervera, M.; Martinez-Zapater, J. DNA methylation increases throughout Arabidopsis development. Planta 2005, 222, 301-306. [CrossRef] [PubMed]

51. Zluvova, J.; Janousek, B.; Vyskot, B. Immunohistochemical study of DNA methylation dynamics during plant development. J. Exp. Bot. 2001, 52, 2265-2273. [CrossRef] [PubMed]

52. Bitonti, M.B.; Cozza, R.; Chiappetta, A.; Giannino, D.; Castiglione, M.R.; Dewitte, W.; Mariotti, D.; Van Onckelen, H.; Innocenti, A.M. Distinct nuclear organization, DNA methylation pattern and cytokinin distribution mark juvenile, juvenile-like and adult vegetative apical meristems in peach (Prunus persica (L.) Batsch). J. Exp. Bot. 2002, 53, 1047-1054. [CrossRef] [PubMed]

53. Widman, N.; Feng, S.; Jacobsen, S.E.; Pellegrini, M. Epigenetic differences between shoots and roots in Arabidopsis reveals tissue-specific regulation. Epigenetics 2014, 9, 236-242. [CrossRef] [PubMed]

54. Zemach, A.; Kim, M.Y.; Silva, P.; Rodrigues, J.A.; Dotson, B.; Brooks, M.D.; Zilberman, D. Local DNA hypomethylation activates genes in rice endosperm. Proc. Natl. Acad. Sci. USA 2010, 107, 18729-18734. [CrossRef] [PubMed]

55. Hsieh, T.F.; Ibarra, C.A.; Silva, P.; Zemach, A.; Eshed-Williams, L.; Fischer, R.L.; Zilberman, D. Genome-wide demethylation of Arabidopsis endosperm. Science 2009, 324, 1451-1454. [CrossRef] [PubMed]

56. Kawakatsu, T.; Stuart, T.; Valdes, M.; Breakfield, N.; Schmitz, R.J.; Nery, J.R.; Urich, M.A.; Han, X.; Lister, R.; Benfey, P.N. Unique cell-type-specific patterns of DNA methylation in the root meristem. Nat. Plants 2016, 2, 16058. [CrossRef] [PubMed]

57. Song, Q.-X.; Lu, X.; Li, Q.-T.; Chen, H.; Hu, X.-Y.; Ma, B.; Zhang, W.-K.; Chen, S.-Y.; Zhang, J.-S. Genome-wide analysis of DNA methylation in soybean. Mol. Plant 2013, 6, 1961-1974. [CrossRef] [PubMed]

58. Walker, J.; Gao, H.; Zhang, J.; Aldridge, B.; Vickers, M.; Higgins, J.D.; Feng, X. Sexual-lineage-specific DNA methylation regulates meiosis in Arabidopsis. Nat. Genet. 2018, 50, 130-137. [CrossRef] [PubMed]

59. Kawashima, T.; Berger, F. Epigenetic reprogramming in plant sexual reproduction. Nat. Rev. Genet. 2014, 15, 613-624. [CrossRef] [PubMed]

60. Hsieh, P.-H.; He, S.; Buttress, T.; Gao, H.; Couchman, M.; Fischer, R.L.; Zilberman, D.; Feng, X. Arabidopsis male sexual lineage exhibits more robust maintenance of CG methylation than somatic tissues. Proc. Natl. Acad. Sci. USA 2016, 113, 15132-15137. [CrossRef] [PubMed]

61. Calarco, J.P.; Borges, F.; Donoghue, M.T.; Van Ex, F.; Jullien, P.E.; Lopes, T.; Gardner, R.; Berger, F.; Feijo, J.A.; Becker, J.D.; et al. Reprogramming of DNA methylation in pollen guides epigenetic inheritance via small RNA. Cell 2012, 151, 194-205. [CrossRef] [PubMed]

62. Ibarra, C.A.; Feng, X.; Schoft, V.K.; Hsieh, T.F.; Uzawa, R.; Rodrigues, J.A.; Zemach, A.; Chumak, N.; Machlicova, A.; Nishimura, T.; et al. Active DNA demethylation in plant companion cells reinforces transposon methylation in gametes. Science 2012, 337, 1360-1364. [CrossRef] [PubMed]

63. Lin, J.Y.; Le, B.H.; Chen, M.; Henry, K.F.; Hur, J.; Hsieh, T.F.; Chen, P.Y.; Pelletier, J.M.; Pellegrini, M.; Fischer, R.L.; et al. Similarity between soybean and Arabidopsis seed methylomes and loss of non-CG methylation does not affect seed development. Proc. Natl. Acad. Sci. USA 2017, 114, E9730-E9739. [CrossRef] [PubMed]

64. Becker, C.; Hagmann, J.; Muller, J.; Koenig, D.; Stegle, O.; Borgwardt, K.; Weigel, D. Spontaneous epigenetic variation in the Arabidopsis thaliana methylome. Nature 2011, 480, 245-249. [CrossRef] [PubMed]

65. Ganguly, D.R.; Crisp, P.A.; Eichten, S.R.; Pogson, B.J. The Arabidopsis DNA Methylome Is Stable under Transgenerational Drought Stress. Plant Physiol. 2017, 175, 1893-1912. [CrossRef] [PubMed]

66. Cokus, S.J.; Feng, S.; Zhang, X.; Chen, Z.; Merriman, B.; Haudenschild, C.D.; Pradhan, S.; Nelson, S.F.; Pellegrini, M.; Jacobsen, S.E. Shotgun bisulphite sequencing of the Arabidopsis genome reveals DNA methylation patterning. Nature 2008, 452, 215-219. [CrossRef] [PubMed]

67. Lanfear, R. Do plants have a segregated germline? PLoS Biol. 2018, 16, e2005439. [CrossRef] [PubMed]

68. Kinoshita, T.; Yadegari, R.; Harada, J.J.; Goldberg, R.B.; Fischer, R.L. Imprinting of the MEDEA polycomb gene in the Arabidopsis endosperm. Plant Cell 1999, 11, 1945-1952. [CrossRef] [PubMed] 
69. Kinoshita, T.; Miura, A.; Choi, Y.; Kinoshita, Y.; Cao, X.; Jacobsen, S.E.; Fischer, R.L.; Kakutani, T. One-way control of FWA imprinting in Arabidopsis endosperm by DNA methylation. Science 2004, 303, 521-523. [CrossRef] [PubMed]

70. Jullien, P.E.; Kinoshita, T.; Ohad, N.; Berger, F. Maintenance of DNA methylation during the Arabidopsis life cycle is essential for parental imprinting. Plant Cell 2006, 18, 1360-1372. [CrossRef] [PubMed]

71. Hsieh, T.F.; Shin, J.; Uzawa, R.; Silva, P.; Cohen, S.; Bauer, M.J.; Hashimoto, M.; Kirkbride, R.C.; Harada, J.J.; Zilberman, D.; et al. Regulation of imprinted gene expression in Arabidopsis endosperm. Proc. Natl. Acad. Sci. USA 2011, 108, 1755-1762. [CrossRef] [PubMed]

72. Kohler, C.; Wolff, P.; Spillane, C. Epigenetic mechanisms underlying genomic imprinting in plants. Annu. Rev. Plant Biol. 2012, 63, 331-352. [CrossRef] [PubMed]

73. Jahnke, S.; Scholten, S. Epigenetic Resetting of a Gene Imprinted in Plant Embryos. Curr. Biol. 2009, 19, 1677-1681. [CrossRef] [PubMed]

74. Park, J.S.; Frost, J.M.; Park, K.; Ohr, H.; Park, G.T.; Kim, S.; Eom, H.; Lee, I.; Brooks, J.S.; Fischer, R.L.; et al. Control of DEMETER DNA demethylase gene transcription in male and female gamete companion cells in Arabidopsis thaliana. Proc. Natl. Acad. Sci. USA 2017, 114, 2078-2083. [CrossRef] [PubMed]

75. Slotkin, R.K.; Vaughn, M.; Borges, F.; Tanurdzic, M.; Becker, J.D.; Feijo, J.A.; Martienssen, R.A. Epigenetic reprogramming and small RNA silencing of transposable elements in pollen. Cell 2009, 136, 461-472. [CrossRef] [PubMed]

76. Martinez, G.; Wolff, P.; Wang, Z.; Moreno-Romero, J.; Santos-Gonzalez, J.; Conze, L.L.; DeFraia, C.; Slotkin, R.K.; Kohler, C. Paternal easiRNAs regulate parental genome dosage in Arabidopsis. Nat. Genet. 2018, 50, 193-198. [CrossRef] [PubMed]

77. Klosinska, M.; Picard, C.L.; Gehring, M. Conserved imprinting associated with unique epigenetic signatures in the Arabidopsis genus. Nat. Plants 2016, 2, 16145. [CrossRef] [PubMed]

78. Narsai, R.; Gouil, Q.; Secco, D.; Srivastava, A.; Karpievitch, Y.V.; Liew, L.C.; Lister, R.; Lewsey, M.G.; Whelan, J. Extensive transcriptomic and epigenomic remodelling occurs during Arabidopsis thaliana germination. Genome Biol. 2017, 18, 172. [CrossRef] [PubMed]

79. Kawakatsu, T.; Nery, J.R.; Castanon, R.; Ecker, J.R. Dynamic DNA methylation reconfiguration during seed development and germination. Genome Biol. 2017, 18, 171. [CrossRef] [PubMed]

80. Bouyer, D.; Kramdi, A.; Kassam, M.; Heese, M.; Schnittger, A.; Roudier, F.; Colot, V. DNA methylation dynamics during early plant life. Genome Biol. 2017, 18, 179. [CrossRef] [PubMed]

81. Van Zanten, M.; Koini, M.A.; Geyer, R.; Liu, Y.; Brambilla, V.; Bartels, D.; Koornneef, M.; Fransz, P.; Soppe, W.J. Seed maturation in Arabidopsis thaliana is characterized by nuclear size reduction and increased chromatin condensation. Proc. Natl. Acad. Sci. USA 2011, 108, 20219-20224. [CrossRef] [PubMed]

82. Xing, M.Q.; Zhang, Y.J.; Zhou, S.R.; Hu, W.Y.; Wu, X.T.; Ye, Y.J.; Wu, X.X.; Xiao, Y.P.; Li, X.; Xue, H.W. Global Analysis Reveals the Crucial Roles of DNA Methylation during Rice Seed Development. Plant Physiol. 2015, 168, 1417-1432. [CrossRef] [PubMed]

83. Grover, J.W.; Kendall, T.; Baten, A.; Burgess, D.; Freeling, M.; King, G.J.; Mosher, R.A. Maternal components of RNA-directed DNA methylation are required for seed development in Brassica rapa. Plant J. 2018, 94, 575-582. [CrossRef] [PubMed]

84. Hossain, M.S.; Kawakatsu, T.; Kim, K.D.; Zhang, N.; Nguyen, C.T.; Khan, S.M.; Batek, J.M.; Joshi, T.; Schmutz, J.; Grimwood, J.; et al. Divergent cytosine DNA methylation patterns in single-cell, soybean root hairs. New Phytol. 2017, 214, 808-819. [CrossRef] [PubMed]

85. Yao, Y.; Bilichak, A.; Golubov, A.; Kovalchuk, I. $d d m 1$ plants are sensitive to methyl methane sulfonate and $\mathrm{NaCl}$ stresses and are deficient in DNA repair. Plant Cell Rep. 2012, 31, 1549-1561. [CrossRef] [PubMed]

86. Xu, R.; Wang, Y.; Zheng, H.; Lu, W.; Wu, C.; Huang, J.; Yan, K.; Yang, G.; Zheng, C. Salt-induced transcription factor MYB74 is regulated by the RNA-directed DNA methylation pathway in Arabidopsis. J. Exp. Bot. 2015, 66, 5997-6008. [CrossRef] [PubMed]

87. Shen, Y.; Conde, E.S.N.; Audonnet, L.; Servet, C.; Wei, W.; Zhou, D.X. Over-expression of histone H3K4 demethylase gene JMJ15 enhances salt tolerance in Arabidopsis. Front. Plant Sci. 2014, 5, 290. [CrossRef] [PubMed]

88. Lopez, A.; Ramirez, V.; Garcia-Andrade, J.; Flors, V.; Vera, P. The RNA silencing enzyme RNA polymerase v is required for plant immunity. PLoS Genet. 2011, 7, e1002434. [CrossRef] [PubMed] 
89. Yu, A.; Lepere, G.; Jay, F.; Wang, J.; Bapaume, L.; Wang, Y.; Abraham, A.L.; Penterman, J.; Fischer, R.L.; Voinnet, O.; et al. Dynamics and biological relevance of DNA demethylation in Arabidopsis antibacterial defense. Proc. Natl. Acad. Sci. USA 2013, 110, 2389-2394. [CrossRef] [PubMed]

90. Dowen, R.H.; Pelizzola, M.; Schmitz, R.J.; Lister, R.; Dowen, J.M.; Nery, J.R.; Dixon, J.E.; Ecker, J.R. Widespread dynamic DNA methylation in response to biotic stress. Proc. Natl. Acad. Sci. USA 2012, 109, E2183-E2191. [CrossRef] [PubMed]

91. Slaughter, A.; Daniel, X.; Flors, V.; Luna, E.; Hohn, B.; Mauch-Mani, B. Descendants of primed Arabidopsis plants exhibit resistance to biotic stress. Plant Physiol. 2012, 158, 835-843. [CrossRef] [PubMed]

92. Luna, E.; Ton, J. The epigenetic machinery controlling transgenerational systemic acquired resistance. Plant Signal. Behav. 2012, 7, 615-618. [CrossRef] [PubMed]

93. Lopez Sanchez, A.; Stassen, J.H.; Furci, L.; Smith, L.M.; Ton, J. The role of DNA (de)methylation in immune responsiveness of Arabidopsis. Plant J. 2016, 88, 361-374. [CrossRef] [PubMed]

94. Mirouze, M.; Paszkowski, J. Epigenetic contribution to stress adaptation in plants. Curr. Opin. Plant Biol. 2011, 14, 267-274. [CrossRef] [PubMed]

95. Heard, E.; Martienssen, R.A. Transgenerational epigenetic inheritance: Myths and mechanisms. Cell 2014, 157, 95-109. [CrossRef] [PubMed]

96. Reinders, J.; Wulff, B.B.; Mirouze, M.; Mari-Ordonez, A.; Dapp, M.; Rozhon, W.; Bucher, E.; Theiler, G.; Paszkowski, J. Compromised stability of DNA methylation and transposon immobilization in mosaic Arabidopsis epigenomes. Genes Dev. 2009, 23, 939-950. [CrossRef] [PubMed]

97. Lira-Medeiros, C.F.; Parisod, C.; Fernandes, R.A.; Mata, C.S.; Cardoso, M.A.; Ferreira, P.C. Epigenetic variation in mangrove plants occurring in contrasting natural environment. PLoS ONE 2010, 5, e10326. [CrossRef] [PubMed]

98. Gong, Z.; Morales-Ruiz, T.; Ariza, R.R.; Roldan-Arjona, T.; David, L.; Zhu, J.-J. ROS1, a Repressor of Transcriptional Gene Silencing in Arabidopsis, Encodes a DNA Glycosylase/Lyase. Cell 2002, 111, 803-814. [CrossRef]

99. Williams, B.P.; Pignatta, D.; Henikoff, S.; Gehring, M. Methylation-sensitive expression of a DNA demethylase gene serves as an epigenetic rheostat. PLoS Genet. 2015, 11, e1005142. [CrossRef] [PubMed]

100. Lei, M.; Zhang, H.; Julian, R.; Tang, K.; Xie, S.; Zhu, J.K. Regulatory link between DNA methylation and active demethylation in Arabidopsis. Proc. Natl. Acad. Sci. USA 2015, 112, 3553-3557. [CrossRef] [PubMed]

101. Ji, L.; Chen, X. Regulation of small RNA stability: Methylation and beyond. Cell Res. 2012, 22, $624-636$. [CrossRef] [PubMed]

102. He, X.J.; Hsu, Y.F.; Zhu, S.; Wierzbicki, A.T.; Pontes, O.; Pikaard, C.S.; Liu, H.L.; Wang, C.S.; Jin, H.; Zhu, J.K. An effector of RNA-directed DNA methylation in arabidopsis is an ARGONAUTE 4- and RNA-binding protein. Cell 2009, 137, 498-508. [CrossRef] [PubMed]

103. Bies-Etheve, N.; Pontier, D.; Lahmy, S.; Picart, C.; Vega, D.; Cooke, R.; Lagrange, T. RNA-directed DNA methylation requires an AGO4-interacting member of the SPT5 elongation factor family. EMBO Rep. 2009, 10, 649-654. [CrossRef] [PubMed]

104. Huang, Y.; Ji, L.; Huang, Q.; Vassylyev, D.G.; Chen, X.; Ma, J.B. Structural insights into mechanisms of the small RNA methyltransferase HEN1. Nature 2009, 461, 823-827. [CrossRef] [PubMed]

105. Zhou, M.; Palanca, A.M.S.; Law, J.A. Locus-specific control of the de novo DNA methylation pathway in Arabidopsis by the CLASSY family. Nat. Genet. 2018, 50, 865-873. [CrossRef] [PubMed]

106. Singh, M.; Goel, S.; Meeley, R.B.; Dantec, C.; Parrinello, H.; Michaud, C.; Leblanc, O.; Grimanelli, D. Production of viable gametes without meiosis in maize deficient for an ARGONAUTE protein. Plant Cell 2011, 23, 443-458. [CrossRef] [PubMed]

107. Vu, T.M.; Nakamura, M.; Calarco, J.P.; Susaki, D.; Lim, P.Q.; Kinoshita, T.; Higashiyama, T.; Martienssen, R.A.; Berger, F. RNA-directed DNA methylation regulates parental genomic imprinting at several loci in Arabidopsis. Development 2013, 140, 2953-2960. [CrossRef] [PubMed]

108. Manning, K.; Tor, M.; Poole, M.; Hong, Y.; Thompson, A.J.; King, G.J.; Giovannoni, J.J.; Seymour, G.B. A naturally occurring epigenetic mutation in a gene encoding an SBP-box transcription factor inhibits tomato fruit ripening. Nat. Genet. 2006, 38, 948-952. [CrossRef] [PubMed]

109. Verhoeven, K.J.; Jansen, J.J.; van Dijk, P.J.; Biere, A. Stress-induced DNA methylation changes and their heritability in asexual dandelions. New Phytol. 2010, 185, 1108-1118. [CrossRef] [PubMed] 
110. Suter, L.; Widmer, A. Environmental heat and salt stress induce transgenerational phenotypic changes in Arabidopsis thaliana. PLoS ONE 2013, 8, e60364. [CrossRef] [PubMed]

111. Lister, R.; O’Malley, R.C.; Tonti-Filippini, J.; Gregory, B.D.; Berry, C.C.; Millar, A.H.; Ecker, J.R. Highly integrated single-base resolution maps of the epigenome in Arabidopsis. Cell 2008, 133, 523-536. [CrossRef] [PubMed]

112. Zilberman, D.; Coleman-Derr, D.; Ballinger, T.; Henikoff, S. Histone H2A.Z and DNA methylation are mutually antagonistic chromatin marks. Nature 2008, 456, 125-129. [CrossRef] [PubMed]

113. Seymour, D.K.; Koenig, D.; Hagmann, J.; Becker, C.; Weigel, D. Evolution of DNA methylation patterns in the Brassicaceae is driven by differences in genome organization. PLoS Genet. 2014, 10, e1004785. [CrossRef] [PubMed]

114. Keller, T.E.; Yi, S.V. DNA methylation and evolution of duplicate genes. Proc. Natl. Acad. Sci. USA 2014, 111, 5932-5937. [CrossRef] [PubMed]

(C) 2018 by the authors. Licensee MDPI, Basel, Switzerland. This article is an open access article distributed under the terms and conditions of the Creative Commons Attribution (CC BY) license (http://creativecommons.org/licenses/by/4.0/). 